\title{
ASSESSMENT OF THE PERFORMANCE OF NATIONAL SPECIAL PROGRAMME FOR FOOD SECURITY IN NIGER STATE, NIGERIA
}

\author{
Atteh A.P. \\ Department of Agricultural Economics and Extension, Federal University of Lafia, Nasarawa State, \\ Nigeria
}

Article DOI: https://doi.org/10.36713/epra6646

DOI No: 10.36713/epra6646

\begin{abstract}
The study assessed the performance of the National Special Programme for Food Security (NSPFS) in Niger State, Nigeria. A total of 180 respondents were selected using multistage sampling technique. The project sites were chosen purposively comprising of all the nine sites of NSPFS in Niger State, namely; Nassarawa, Batavovogi, Lenfa-Bororo, Gidan-Mangoro, Garam, Mankangara, Lioji, Kaboji and Shambo. The respondents were selected proportionately based on each site's activities. Data collection lasted from 15th February, 2013 to 31 st August, 2013. Data were analyzed using descriptive statistics such as percentages and means, frequency distribution, performance indices computation. The results of the analysis showed that, the mean age of the beneficiaries was 47.82 years, farming experience was 30 years. The mean age for non-beneficiaries was 43.59 years, farming experience was 25 years. The results of the analysis further indicated that there was high performance in the following components: existing primary groups (100\%), amount of money in the account (100\%), existing modules in the site $(73.53 \%)$, and loan disbursement (99.30\%), based on the performance indices. Crop enterprises recorded low performance (63.61\%). The study concluded that the performance of the NSPFS was high in the following components: number of primary groups existing, apex amount of money in the account, existing modules in the site, and grouping based on gender for easy accessibility, loan disbursement and farm animal enterprises. It was recommended that the NSPFS should focus more attention on mechanization, storage facilities, agro-processing, marketing, small scale irrigation, and infrastructure, because it will help the benefitting famers to actualize their pre-determined goals, it will also improve their well-being.
\end{abstract}

KEYWORDS: Food, Security, Food Security, Agricultural Science

\section{INTRODUCTION}

Plummeting food insecurity continues to be a major public policy challenge in developing countries (Abu, 2012). Achievement of food security in any country is typically an insurance against hunger and malnutrition, both of which hinder economic development (Davies, 2009). This explains why all developed and some developing countries make considerable efforts to increase their food production capacity. According to the Food and Agriculture Organization (FAO) (2008), approximately one billion people worldwide are under-nourished, many more suffer from micro-nutrient deficiencies, and the absolute numbers of the people tend to increase further, 


\section{SJIF Impact Factor 2021: 8.013| ISI I.F.Value:1.241| Journal DOI: 10.36713/epra2016 ISSN: 2455-7838(Online) EPRA International Journal of Research and Development (IJRD) Volume: 6 | Issue: 4 | April 2021 \\ - Peer Reviewed Journal}

most especially in Sub-Saharan Africa (SSA). The World Bank (1986) proposed a definition of food security, which remains current today broadening the emphasis from food availability to include access to food, and narrowing the focus from global and national to households and individuals: "access by all people at all times to enough food for an active life."

According to Wibberley, (2005) food security at household, village, national and international levels require the availability of adequate quantity and quality of locally-grown agricultural products; accessibility of supplies for urban and land-remote areas, appreciation of the close link between nutrition and health for work and enjoyment; avoidance of undue risk through livelihood vulnerability, hazard and shock in reserves. Maziya-Dixton, Akinyele, Oguntona, Nokoe, Sanusi, and Harris, (2004) defined food security as the access at all times by the people, either through own production or through purchase of enough food for active, healthy life. Food security exists when every person has physical and economic access at all times to healthy, nutritious food in sufficient quantity to cover the need of their daily ration and food preferences, in order to live a healthy, and active life (Sengooba, 1994). In a situation where this does not occur, we have food insecurity. It may be chronic or transitory. In chronic food insecurity, there is continuous inadequate diet and nutrition caused by the household's inability to acquire food. It manifests in the form of persistent inability to either buy food or produce food on their own, on the other hand, transitory food insecurity results from a temporary decline in household access to food due mainly to instability in food price, production, household income or a combination of these factors in a critical situation.

In Africa, food insecurity remains a fundamental challenge and both cases of food insecurity abound often existing together and jointly predisposing affected individuals to disease and reduced vigor, vitality and the strength needed for physical tasks, mental retardation e.t.c. (World Bank, 2004). The issue of food insecurity is of high importance to Nigeria because, average calories and protein intake is only at the threshold of adequacy. Estimates show that, at least $41 \%$ of the population is food insecure; with $16 \%$ being severely under nourished in Nigeria and also in Sub-Sahara Africa (World Bank and International Food Policy Research Institute (IFPRI, 2006).

In Nigeria, two-thirds of the population lives below the poverty line and household food security is inadequate (Vision, 2010). Nigerians suffer both income and food poverty, and poor access to the means of supporting rural development among other causative factors (World Health Organization (WHO) (2004). Consequently, food security which goes with food selfsufficiency and sustainability is still elusive (Nworgu, 2006). This is because, the agricultural sector has not been able to deal effectively with the problem of food security for the Nigerian people when viewed from the stand points of the nutritional status of Nigerians, household food security and food prices (Vision, 2010).

One of the Millennium Development Goals (MDGs) is to eradicate extreme poverty and food insecurity completely before 2015 , but at present, the proportion of people who suffer from extreme hunger and people whose income is less than $\$ 2$ per day are very high (United Nations Development Programme (UNDP), 2010). The achievement of this target is very important in reducing hunger and poverty. This is because, it is believed that, hunger perpetuates poverty by reducing productivity and healthy living which, in turn prevents people from producing or acquiring the food they need. FAO (2005) observed that Nigeria has barely one year of expecting to eradicate food insecurity which does not look feasible going by the available statistics. To buttress this point, (World Bank and IFPRI, 2006) had earlier reported that over $40 \%$ of households across all agro-ecological zones in Nigeria face the problem of severe food insecurity.

The worsening levels of productivity and poverty in rural areas directly threaten the food security and living conditions of the average Nigerian. More than $95 \%$ of Nigeria's food supply comes from the small scale agricultural sector dominated by poor peasant farmers or small scale farmers whose productivity is constrained by their extremely low educational standards, inadequate land or land tenure problem, low level of capital, limited access to the market, poor access to credit facilities, low productivity, low levels of modern technology, and other resource inputs (Kankwenda, Gregoire, Legros, \& Ouedraogo, 2010). Food insecurity, even though not widespread, is a common phenomenon in Niger State (Vision 3:2020). There is dearth of documented evidence in this regard. Satisfying the population's food requirements has remained evasive with resultant food shortages and malnutrition particularly among the low income groups (Vision, 2010). National Special Programme for Food Security (NSPFS) started its operation in Niger State in 2002, which covered the three agricultural zones in the State. This research work 


\section{SJIF Impact Factor 2021: 8.013| ISI I.F.Value:1.241| Journal DOI: 10.36713/epra2016 ISSN: 2455-7838(Online) EPRA International Journal of Research and Development (IJRD)}

Volume: 6 | Issue: 4 | April 2021

- Peer Reviewed Journal

assessed the performance of the programme in the State.

\section{The Concepts of Food Security and Economic Development}

Nyam, (2005) defines food security as access by all people at all times to sufficient food for a healthy and productive life. Lenis et al., (2011) asserts the definition of food security tailored along the definition of the World Food Summit held in Rome in 1996 to mean the right of everyone to have access to safe and nutritious food, consistent with the right of everyone to be free from hunger. Odey, (2004) articulates food security system definition as the availability and accessibility of foodstuff in desired quality to all consumers throughout the year. Gokum, (2007) while, acknowledging that the food security concept took its roots around the mid-1970s in the discussions of International food problems at a time of global food crisis he adopted the definition of the World Food Summit in 1996 to say, food security is the availability at all times of adequate world food supplies of basic food stuff to sustain a steady expansion of food consumption and to offset fluctuation in production and prices. The Food and Agriculture Organization (FAO) (2002) succinctly captures the definition of food security concept by stating that food security is a situation that exist when all people at all times have physical, social and economic access to sufficient, safe and nutritious food that meet their dietary needs and food preferences for an active and healthy life. In essence, the underlying theme of the food security concept underscores the accessibility of the community's or individual's dietary needs at all times, which behooves as a moral obligation on all human beings to ensure that this topmost priority amongst the basic requisites of man is met for his survival.

Economic growth and development concepts are used interchangeably. It is worthy to note that these two concepts do not mean exactly the same thing as Food Security and Nutrition Working Group, (2012) agree no other by asserting that sustained economic growth overtime leads to economic development. He espoused that economic development would mean there is equitable distribution of increased output among individuals and areas such that the increased output is not concentrated in the hands of a few, the increased output is not counteracted by rapid population growth and the increasing level of production does not lead to massive unemployment as a result of labour saving devices or mode of production. Oni et al., (2009) defines economic growth as the increase of an economy's capacity to produce goods and services needed to improve the well-being of the citizen in increasing number and diversity.

According to Emmanuel, (2004) explained economic growth as the process which leads to substantial increase in the actual output of goods and services per head. Todaro and Smith, (2003) perceives economic development as multi-dimensional process involving the organization and reorientation of the entire economy and social system which involves radical changes in institution, social and administrative structure as well as popular attitudes, custom and belief. This structural change involve virtually all economic functions including the transformation of production, changes in the composition of consumer demand, international trade and resources use as well as urbanization, growth and distribution of a country's population. Economic development simply entails a sustained economic growth recorded overtime.

The Malthusian economics has articulated an arithmetic progression in food production given that the world population growth rate would be in geometric quantum. This view presupposed a dis-equilibrating scenario of shortages in food production to meet up the ever increasing population growth rate. This disequilibrating scenario was further articulated by the Marshalian economists who linked supply and demand in the context of time, which explains why some economists have argued that with the advent of technological improvements the gloom story as painted by Malthus would be far from achieving its postulates. However most recently, Oni et al., (2009) have argued that, the concept of world food surplus is extremely mischievous. They contended that sustainable production depends on maintaining the carrying capacity which is a prerequisite to that production. Yet maintenance of agricultural and indeed, the whole earth's ecological carrying capacity, depend on limiting the human population growth which increasingly impairs it.

The Natural Environment Research Council Centre for Atmospheric Science situated in the University of Reading, United Kingdom reports that staple food conditions is most efficient in the tropics. This avail reasons why the most supply of staple foods is in the tropics e.g. rice and maize. The centre maintains that tropical regions experience large changes in weather and climate year to year, therefore making food production highly vulnerable to the variations in climatic conditions. The centre therefore 


\section{SJIF Impact Factor 2021: 8.013| ISI I.F.Value:1.241| Journal DOI: 10.36713/epra2016 ISSN: 2455-7838(Online) EPRA International Journal of Research and Development (IJRD) Volume: 6 | Issue: 4 | April 2021 \\ - Peer Reviewed Journal}

contends that reliable seasonal forecast of crop yield would be of real benefit to farmers and could assist with famine early warning systems. Discussions by Angus, (2008); Vidal, (2007; Collier, (2008) on the reasons of global crisis in prices and production of staple foods and other agricultural products reveal that natural shock such as droughts, growing population, net food importation by African countries, reduced assistance and investments by developed countries to the developing economies by the end of the green revolution era, conversion of food into fuel and animal feed, the linkage of food prices to oil prices, have contributed to reasons for the crisis. Dorelien, (2008) paper captures the above views more succinctly as he posits that "the prices of agricultural commodities, including staples of many African diets, have risen sharply over the last several years. The sharpest rises have been within the past six months. Since 2005, the prices of maize and wheat have doubled and the price of rice has now reached unprecedented levels.

According to World Bank, the Food and Agricultural Organization of the United Nations, the United States Department of Agriculture, and these rising prices are likely to persist through 2015 . The factors leading to increased prices and resultant food crisis are diverse and complex. Most factors however, can be thought of as having impacts on the supply of food and/or the demand for food. The supply of food may be affected by land and water constraints, under investment in rural infrastructure and agriculture, lack of access to fertilizer and irrigation, trade policies and weather disruptions. Factors that affect the demand for food include rising energy prices and conversions of crop lands to bio fuel production, population growth, globalization of food markets and changing diets. The current food crisis is the simplest terms a result of rapid growth in food demand in conjunction with a decline in the growth of food supply". This evolving global crisis has recorded serious consequences on developed and developing economies.

Emmanuel, (2004) posited that for the past 20 years, many African countries that have been food exporters have become net importers. Not only have they become dependent on foreign aid, but their increasing food bill has become a serious budgetary and political obstacle to progress and growth. Vidal, (2007) reporting on the crisis said that this crisis has led to $18 \%$ food price inflation in China, $13 \%$ in Indonesia and Pakistan and $10 \%$ or more in Latin America, Russia and India. He further reveals that, according to UN Food and Agriculture Organization, wheat has doubled in price, maize is nearly $50 \%$ higher than a year ago and rice is $20 \%$ more expensive. Global food reserves are at their lowest in 25 years. Collier, (2008) captures these evolving consequences of food crisis more succinctly as he says that "the sharp increase in world price of staple food is an inconvenience for consumer in the rich world, but for consumers in the poorest countries, especially in Africa, it is a catastrophe" Joint field evaluation survey conducted by the National Agricultural Extension and Research Liaison Services (NAERLS), the Federal Department of Agriculture and National Food Reserve Agency (NFRA), (2007) in Andohol (2012) report avails that markets in West Africa are highly integrated and price changes due to supply or demand shocks are easily transmitted among neighbouring countries, especially any reduction in Nigeria staple food production, by far the largest economy and agricultural sector in the region, usually pushes up regional prices, and seriously affecting food security in neighbouring countries.

\section{STATEMENT OF THE PROBLEM}

The Federal Government of Nigeria plans to extend the NSPFS to other areas of the country at the end of the pilot phase in line with one of the Millennium Development Goals (MDGs) which is to eradicate extreme poverty and hunger by halving the proportion of people in Nigeria whose income are very low to come by, thereby reducing the proportion of people who suffer from hunger between 1990 and 2015 (MDGs, 2004). Nigeria is blessed with fertile land (Vision, 2010) but, yet cannot provide enough food for her teeming populace, unless complemented with net food importation (Yusuf, Baba, Mohammed \& Dogondaji, 2009). In the early 60 's to mid-80's Nigeria had the ability to meet up with her food requirements. All of a sudden, something went wrong (Oni, Pender, Philips \& Kato, 2009). Therefore, if there will be sufficient food supply for her citizenry, certain checks must be put in place. This study aims at assessing the performance of the National Special Programme for Food Security in Niger State. The State plays a vital role as an agrarian State that possesses fertile agricultural land as a cherished asset whose potentials in securing food productions are yet to be fully exploited (Vision, 2010).

The even climate, rich annual rainfall and availability of wide variety of minerals and agricultural resources all attest to the economic potential of the State, as one that will be food secure, if properly managed (Niger State Ministry of Agriculture (NSMA) 


\section{SJIF Impact Factor 2021: 8.013| ISI I.F.Value:1.241| Journal DOI: 10.36713/epra2016 ISSN: 2455-7838(Online) EPRA International Journal of Research and Development (IJRD) Volume: 6 | Issue: 4 | April 2021 \\ - Peer Reviewed Journal}

(2011). The State is surrounded with water to power engines needed for agricultural food production. The three hydro-electricity power stations i.e Kainji, Jebba and Shiroro dams are evidence (Niger State Ministry of Information (NSMI) (2012). Based on the foregoing, it can be said that despite the great potential that the State has in resolving food crisis, pockets of the population are still food insecure. Does this mean that the NSPFS programme like the previous programmes has not performed as expected? What can be done to put the poor and vulnerable groups on board the train of a food secure society?

\section{OBJECTIVES OF THE STUDY}

The broad objective of this study was to assess the performance of the National Special Programme for Food Security (NSPFS) in Niger State, Nigeria. The specific objectives of this study will be to:

1. Identify the socio-economic characteristics of participating farmers in the project sites;

2. Measure the performance of the programme in the achievement of predetermined objectives.

\section{Research Questions}

Against this backdrop, the following research questions are hereby deemed appropriate for this study;

1. What are the socio-economic characteristics of the participating farmers in the selected project sites?

2. What is the performance of the programme in the achievement of predetermined objectives?

\section{METHODOLOGY}

This study adopted descriptive research of survey design which comprises of selected farmers in Niger state. Multistage sampling procedure was employed in the selection of respondents for the study. The first stage involved purposive selection of the programme sites in the three agricultural zones in the State namely; Zones I, II, and III. There were nine project sites in the whole State. The second stage involved the selection of L.G.As in the respective project sites. This selection was purposive because, only L.G.As where project sites are domiciled was selected. The third stage involved the purposive selection of farming communities/villages that had benefited from the programme. The field survey indicated that, the State have nine sites which comprise of farming communities/villages that have benefitted from the programme. All the nine sites formed the sampling frame for the purpose of this research work, namely: Nassarawa, Batavovogi, Lenfa-Bororo, GidanMangoro, Garam, Makangara, Lioji, Kaboji, and Shambo. The benefitting communities were purposively selected as follows: From Zone I (with headquarters in Nasarawa), three sites, namely, Nasarawa, Batavovogi and Lenfa-Bororo were selected; while Gidan-Mangoro, Garam and Makangara were purposively selected from Zone II with headquarters at Gidan-Mangoro. From Zone III, (whose headquarters was located in Lioji) the following sites were purposively selected Lioji, Kaboji and Shambo respectively. A total of 180 respondents were selected for the study.

The data used for the study were from primary and secondary sources. Data were collected from the respondents using interview schedules (for the nonformal educated farmers) and the questionnaire (for the formal educated farmers) containing both open and close ended questions. Following Ajayi, (2000) and Daudu and Ajayi, (2009) the performance of the programme was measured using a performance index. This was done by using the respondents to indicate the target (expected quantity) and the achieved (actual optimal quantity available at a given time) values in respect of each of the provided innovations.

The model is given as;

$\mathrm{I}_{\mathrm{A}}=\mathrm{QA} / \mathrm{Q} \mathrm{O} \times 100 \%$

Where, $\mathrm{I}_{\mathrm{A}}=$ Availability Index

$\mathrm{Q}_{\mathrm{A}}=$ Quantity actually available

Qo $=$ Optimum quantity at a given critical period.

When $\mathrm{I}_{\mathrm{A}}$ is $\geq 0.5$ or $\geq 50 \%=$ effective performance, otherwise it connotes ineffective performance.

To further assess the performance of the NSPFS, Chow-test was used to test for significant difference in the intercept of production functions between the groups sampled. According to Dougherty (2007), Chow test statistic is often used in programme evaluation to determine whether the programme has impacts on different sub-group populations.

It is express mathematically as;

$$
F=\frac{\mathrm{RSS}-\mathrm{RSS} 1+\mathrm{RSS} 2 / \mathrm{K}}{\mathrm{RSS} 1+\mathrm{RSS} 2 / \mathrm{N} 1+\mathrm{N} 2-2 \mathrm{~K}}
$$

Where, $\mathrm{F}=$ Chow $\mathrm{F}$ 


\section{SJIF Impact Factor 2021: 8.013| ISI I.F.Value:1.241| Journal DOI: 10.36713/epra2016 ISSN: 2455-7838(Online) EPRA International Journal of Research and Development (IJRD) Volume: 6 | Issue: 4 | April 2021

RSS $=$ Residual Sum of Square for pooled sampled.

$\mathrm{RSS}_{1}=$ Residual Sum of square for beneficiaries.

$\mathrm{RSS}_{2}=$ Residual Sum of Square for non-beneficiaries.

$\mathrm{N}_{1}=$ Number of beneficiaries sampled.

$\mathrm{N}_{2}=$ Total number sampled.

$\mathrm{K}=$ Number of parameters.

To be able to compute the sum of squares, a four production function was fitted to the data. The choice of this functional form was based on documented evidence of its wide application in production function estimation in agriculture. Four production function equations were estimated for the participating, non-participating and the pooled samples as follows respectively:

(1) Linear:

$$
\begin{aligned}
& Q_{p}=\beta_{0}+\beta_{1} X_{1}+\beta_{2} X_{2}+\beta_{3} X_{3}+\beta_{4} X_{4}+\beta_{5} X_{5}+e_{1} \\
& Q n=\beta_{o}+\beta_{1} X_{1}+\beta_{2} X_{2}+\beta_{3} X_{3}+\beta_{4} X_{4}+\beta_{5} X_{5}+e_{2} \\
& Q_{p n}=\beta_{0}+\beta_{1} X_{1}+\beta_{2} X_{2}+\beta_{3} X_{3}+\beta_{4} X_{4}+\beta_{5} X_{5}+e_{3} \ldots
\end{aligned}
$$

(2) Semi-logarithmic:

$Q_{p}=\ln \beta_{o}+\beta_{1} \ln X_{1}+\beta_{2} \ln X_{2}+\beta_{3} \ln X_{3}+\beta_{4} \ln X_{4}+\beta_{5} \ln X_{5}+e_{1}$

$Q n=\ln \beta_{0}+\beta_{1} \ln X_{1}+\beta_{2} \ln X_{2}+\beta_{3} \ln X_{3}+\beta_{4} \ln X_{4}+\beta_{5} \ln X_{5}+e_{2}$

$Q_{p n}=\ln \beta_{0}+\beta_{1} \ln X_{1}+\beta_{2} \ln X_{2}+\beta_{3} \ln X_{3}+\beta_{4} \ln X_{4}+\beta_{5} \ln X_{5}+e_{3}$

(3) Cobb-Douglas:

$$
\begin{aligned}
& \ln Q_{p}=\ln \beta_{0}+\beta_{1} \ln X_{1}+\beta_{2} \ln X_{2}+\beta_{3} \ln X_{3}+\beta_{4} \ln X_{4}+\beta_{5} \ln X_{5}+e_{1} \ldots \\
& \ln Q_{n}=\ln \beta_{0}+\beta_{1} \ln X_{1}+\beta_{2} \ln X_{2}+\beta_{3} \ln X_{3}+\beta_{4} \ln X_{4}+\beta_{5} \ln X_{5}+e \\
& \ln Q_{p n}=\ln \beta_{o}+\beta_{1} \ln X_{1}+\beta_{2} \ln X_{2}+\beta_{3} \ln X_{3}+\beta_{4} \ln X_{4}+\beta_{5} \ln X_{5}+e_{3}
\end{aligned}
$$

(4) Exponential:

$$
\begin{aligned}
& \ln Q_{p}=\beta_{0}+\beta_{1} X_{1}+\beta_{2} X_{2}+\beta_{3} X_{3}+\beta_{4} X_{4}+\beta_{5} X_{5}+e_{1} \ldots \\
& \ln Q n=\beta_{0}+\beta_{1} X_{1}+\beta_{2} X_{2}+\beta_{3} X_{3}+\beta_{4} X_{4}+\beta_{5} X_{5}+e_{2} \\
& \ln Q_{p n}=\beta_{o}+\beta_{1} X_{1}+\beta_{2} X_{2}+\beta_{3} X_{3}+\beta_{4} X_{4}+\beta_{5} X_{5}+e_{3}
\end{aligned}
$$

Where;

$\mathrm{Q}_{\mathrm{p}}=$ Total value of production for beneficiaries $(\mathrm{N}) /$ ha.,

$\mathrm{Q}_{\mathrm{n}}=$ Total value of production for non-beneficiaries $(\mathrm{N}) /$ ha.,

$\mathrm{Q}_{\mathrm{np}}=, \quad, \quad, \quad, \quad, \quad$ the pooled sample $(\mathrm{N}) /$ ha.,

$\mathrm{X}_{1}$ is the seed input in $\mathrm{Kg} / \mathrm{ha}$.,

$\mathrm{X}_{2}$ is the fertilizer input in $\mathrm{Kg} / \mathrm{ha}$.,

$\mathrm{X}_{3}$ is the agrochemical in litres/ha.,

$\mathrm{X}_{4}$ is the labour input in man-days/ha.,

$\mathrm{X}_{5}$ is the capital input/ha. (Comprising depreciation on agricultural tools and equipment, repairs and operating expenses of implements, rent, interest, payments, e.t.c),

$\mathrm{Ln}=$ natural logarithm,

$\beta_{0}=$ constant term,

$\beta_{1}-\beta_{5}=$ estimated regression coefficients and

$\mathrm{e}_{1}, \mathrm{e}_{2}, \mathrm{e}_{3}=$ respective error terms for participating, non- participating and pooled samples respectively.

\section{RESULTS AND DISCUSSION Socio-economic Characteristics of the Farmers in the Study Area}

The socio-economic characteristics of farmers considered include, age, family size, years of formal education, years of farming experience, gender, farm income total output, marital status e.t.c. Others are hectares of land cultivated, problems faced by the respondents, and other secondary occupations.

\section{Age of Household Head}

The results in Table 1 described the age distribution of the farmers in the study area, the age of a farmer determines the quality and quantity of work he or she can do on his/her farm. This is an important measure of farm productivity. Results in Table 1 show that, majority of the beneficiaries, that is to say $63.79 \%$ and non-beneficiaries $87.50 \%$ are within the age range of 21 and 50 years, which indicates, an agriculturally active age bracket, while $30.17 \%$ of the beneficiaries 


\section{SJIF Impact Factor 2021: 8.013| ISI I.F.Value:1.241| Journal DOI: 10.36713/epra2016 ISSN: 2455-7838(Online) EPRA International Journal of Research and Development (IJRD) \\ Volume: 6 | Issue: 4 | April 2021 \\ - Peer Reviewed Journal}

and $9.38 \%$ of the non- beneficiaries are within the age of 51 and 60 years. This was followed by $6.04 \%$ of the beneficiaries and $3.13 \%$ of non-beneficiaries who are 61 years and above. The mean score of their ages were 47.82 years for the beneficiaries and 43.59 years for the non-beneficiaries. This research work agreed with Adesoji and Oluwatayo, (2011) who also found that majority, i.e (70.6\%) of the respondents were above 35 years of age. This implies that majority of the respondents were within the agriculturally-active age bracket. The age of household head also indicates the ability of a farmer to avert risk due to accumulated experience over time.

\section{Gender Distribution of Respondents}

The results in Table 1 also show the gender distribution of the respondents. Results showed that an overwhelming majority, that is, $(89 \%)$ of the sampled beneficiaries and (78\%) of non-beneficiaries were male, while the remaining $(11 \%)$ of the beneficiaries and $(22 \%)$ of non-beneficiaries were females. This implies that both beneficiaries and non-beneficiaries were predominantly males. This finding agreed with Aneke, (2007) who found that the number of male respondents was higher compared to their female counterpart who were involved in NSPFS. The implication of this is that, there will be gender inequality in food production. In order to provide food security for the populace, female entrepreneurs should be involved. Emmanuel, (2004) in his work advocated for gender equality that is, women need to be carried along, by empowering them to contribute their own quota in food production. They need to be involved in developmental programmes such as the laudable National Special Programme for Food Security.

\section{Farming Experience of the Respondents}

The results in Table 1 show farming experience of the respondents in the study area. The results show that $36.21 \%$ of the beneficiaries under National Special Programme on Food Security in Niger State and $31.25 \%$ of the Non-beneficiaries had farming experience between 21 and 30 years, $31.90 \%$ of the beneficiaries and $26.56 \%$ of the Non-beneficiaries had farming experience of between 31 and 40 years while, $19.83 \%$ of the beneficiaries and $37.50 \%$ of the Nonbeneficiaries had farming experience of between 11 and 20 years. A total of $12.07 \%$ of the beneficiaries and $1.56 \%$ of the Non-beneficiaries had between 41 and 50 years of farming experience, while only $3.13 \%$ of the Non-beneficiaries had farming experience of between 1 and 10 years. The mean for the farming experience was 28 years. The years of farming experience have influence on production, storage and marketing of farm output, because, it is an indication of one is expertise in farming. It is expected that respondents with more years of experience will be able to make good decisions in respect of resource allocation and management of their farms and also enhance their risk taking ability and competence.

Table 1: Distribution of Respondents Based on their Socio-economic Characteristics

\begin{tabular}{ccccc}
\hline \multicolumn{2}{c}{ Beneficiaries } & \multicolumn{2}{c}{ Non-Beneficiaries } \\
\hline \multicolumn{1}{c}{ Variables } & Frequency & Percentage & Frequency & Percentage \\
\hline $\begin{array}{c}\text { Age of Household } \\
\text { head (years) }\end{array}$ & & & & \\
$21-30$ & 2 & 1.72 & 3 & 4.69 \\
$31-40$ & 23 & 19.83 & 24 & 37.50 \\
$41-50$ & 49 & 42.24 & 29 & 45.31 \\
$51-60$ & 35 & 30.17 & 6 & 9.38 \\
$>60$ & 7 & 6.04 & 2 & 3.12 \\
Gender & 103 & 88.79 & 50 & 78.12 \\
$\quad$ Male & 13 & 11.21 & 14 & 21.88 \\
Female & & & & \\
Farming experience & & & & \\
in (years.) & & 0.00 & 2 & \\
1-10 & 0 & & & \\
\hline
\end{tabular}


SJIF Impact Factor 2021: 8.013| ISI I.F.Value:1.241| Journal DOI: 10.36713/epra2016 ISSN: 2455-7838(Online) EPRA International Journal of Research and Development (IJRD) Volume: 6 | Issue: 4 | April 2021 - Peer Reviewed Journal

\begin{tabular}{lclll}
\hline $11-20$ & 23 & 19.83 & 24 & 37.50 \\
$21-30$ & 42 & 36.20 & 20 & 31.25 \\
$31-40$ & 37 & 31.90 & 17 & 26.56 \\
$41-50$ & 14 & 12.07 & 1 & 1.56 \\
\hline
\end{tabular}

Source: Field Survey, 2013

\section{Daily Household Expenditure on Food}

The household head spending determines how buoyant he/she is. This also determines how food will be made available for the family and how easily accessible food is at any point in time. The daily household expenditure on food is presented in Table 2.

Table 2: Daily household expenditure on food

\begin{tabular}{lcc}
\hline \multicolumn{1}{c}{ Amount in ( Naira ) } & Frequency & Percentage (\%) \\
\hline $1-500$ & 9 & 5.00 \\
$501-1,000$ & 43 & 23.89 \\
$1,001-1,500$ & 58 & 32.22 \\
$1,501-2,000$ & 48 & 26.67 \\
$2,001-2,500$ & 12 & 6.67 \\
$2,501-3,000$ & 7 & 3.89 \\
$>3,000$ & 3 & 1.67 \\
Total & $\mathbf{1 8 0}$ & $\mathbf{1 0 0 . 0 0}$ \\
\hline
\end{tabular}

Source: Field Data, 2013

The result obtained showed that, each household head has his own capacity to purchase food to feed his or her family. Table 2 showed that, $32.22 \%$ of them had a purchasing power that range between $N$ $1,001-\$ 1,500$, followed by $26.67 \%$ of the total sampled respondents with $\$ 1,501-\$ 2,000$, then

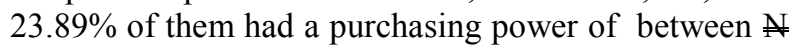
$501-1,000$. A total of $6.67 \%$ of the respondents spent between $\$ 2,001-\$ 2,500$ on a daily basis, $5.00 \%$ of them spent between 1 - $1500,3.89 \%$ spent between $\$ 2,501-\$ 3,000$ on daily basis while $1.67 \%$ of the sampled respondents spent above 3,000 . Food is an indispensable commodity and a necessity. Nyam, (2005) also stated that household food security can be determined by the amount of capital or money a household head has to purchase food for his/her family. The implication of this to the study is that, amount of money boosts access to food at all times and improves food security and makes a household stable.

\section{Assessment of the performance of the National Special Programme for Food Security}

Component indicators were used to assess the performance of the National Special Programme for Food Security, in Niger State. A summary of the component indicators is presented in Table 3 . The performance indices used in this study presented in Table 3 indicated that, the number of primary groups existing were $100 \%$. The performance index of the amount of money in Naira in apex account was also $100 \%$, while number of existing modules in the sites was $73.53 \%$. The number of existing modules fell short of optimal performance index by $26.47 \%$. The performance index for the registered males and females were $100 \%$. The total loan disbursed had a performance index of $99.30 \%$, while crop and animal enterprises had $63.61 \%$, and $72.91 \%$ performance indices respectively. Crop enterprise fell short by $36.39 \%$ and animal enterprise fell short by $27.09 \%$ respectively. 


\section{SJIF Impact Factor 2021: 8.013| ISI I.F.Value:1.241| Journal DOI: 10.36713/epra2016 ISSN: 2455-7838(Online) EPRA International Journal of Research and Development (IJRD)}

Volume: 6 | Issue: 4 | April 2021 - Peer Reviewed Journal

Table 3: Performance indices of the NSPFS farm intensification component as at August, 2013

\begin{tabular}{|c|c|c|c|}
\hline Component indicator & Target level (T) & Actual level (A) & $\begin{array}{l}\text { Performance } \\
\text { index }(\%)\end{array}$ \\
\hline № of primary groups existing & 133 & 133 & $100.00^{*}$ \\
\hline Amount in apex account $(\mathbb{N})$ & $\$ 11,712,433.65$ & $\$ 11,712,433.65$ & $100.00^{*}$ \\
\hline Existing modules in the site & 34 & 25 & $73.53^{*}$ \\
\hline Male group registered & 94 & 94 & $100.00^{*}$ \\
\hline Female group registered & 39 & 39 & $100.00^{*}$ \\
\hline Total loan disbursed ( & $\# 53,273,668$ & $\$ 52,898,668$ & $99.30 *$ \\
\hline Crop enterprises ( $\mathrm{N}$ ) & \# 89,056,785 & $\$ 56,650,890$ & $63.61^{*}$ \\
\hline Animal enterprises ( & $\# 120,679,540$ & $\sharp 87,990,800$ & $72.91^{*}$ \\
\hline
\end{tabular}

\section{*High Performance Index. Source: Field Survey, 2013}

The implication of these results was that any component that recorded higher performance index also turned out to be a profitable enterprise, while low performance index such as; crop enterprise indicated that more attention ought to be placed on them to make it a more productive enterprise. The results agreed with similar findings of Daudu and Ajayi, (2009) who found that the performance indices for virtually all the components were high.

\section{CONCLUSION AND RECOMMENDATIONS}

The study concludes that the performance of the NSPFS was high in the following components: number of primary groups existing, apex amount of money in the account, existing modules in the site, and grouping based on gender for easy accessibility, loan disbursement and farm animal enterprises. The following recommendations were made based on the major findings of the study. The NSPFS should focus more attention on mechanization, storage facilities, agro-processing, marketing, small scale irrigation, and infrastructure, because it will help the benefitting famers to actualize their pre-determined goals, it will also improve their well-being.

\section{REFERENCES}

1. Abu, O. (2012). Food Security in Nigeria and South Africa: Policies and Challenges. Journal of Human Ecology, 38(1), 31-35.

2. Andohol, J. (2012). Nigeria's Food Security Programs: Implications For MDG's Goal Of
Extreme Hunger Eradication. International Journal of Business and Social Science 3(9), 243-253

3. Adesoji, S. A. and Oluwatayo, I. B. (2011). Assessment of Involvement of Women in HouseholdFood Security in Ekiti State, Nigeria. Department of Agricultural Economics and Extension Services, University of Ado-Ekiti, AdoEkiti, Nigeria. The FAMAN Journal 3(4), 18-27

4. Ajayi, A.R. (2000). An ex-post evaluation of the performance indices of the Ekiti-Akoko enclave Agricultural Development Programme, Ondo State, Nigeria. Application for Tropical Agriculture, 5(1), 48-56.

5. Aneke, M.O (2007). Impact of the Phase- 1 National Special Programme on Food Security on Poverty Reduction in Enugu State, Nigeria, A M.sc Thesis, Published edition University of Nigeria, Research Publications, Innovation Centre, Dated 9th May 2009

6. Angus, I. (2008). Food Crisis: The Greatest Demonstration of the Historical Failure of the Capitalist Model. Global Research, April 28.

7. Collier, P. (2008). Food Crisis is a chance to reform global agriculture. Economist Forum; Financial Times, April 30, 2010.

8. Dauda, S. and Ajayi, A.R, (2009). Assessment of the Performance of the National Special Food Security Programme in Benue State, Nigeria. Journal social for sciences, 21 (1), 25-32

9. Davies, A.E. (2009). Food security initiatives in Nigeria: Prospects and Challenges. Journal of Sustainable Development in Africa. 11(1), 186-202.

10. Development Goals? An International Assessment, June 2010. 


\section{SJIF Impact Factor 2021: 8.013| ISI I.F.Value:1.241| Journal DOI: 10.36713/epra2016 ISSN: 2455-7838(Online) EPRA International Journal of Research and Development (IJRD) Volume: 6 | Issue: 4 | April 2021

11. Dorelien, A. (2008). "Population role in the current food crisis Focus on East Africa" Population Reference Bureau.

12. Dougherty, C. (2007). Introduction to Econometrics. Oxford University Press 194.

13. FAO, (2002). "Anti-Hunger Programme: Reducing Hunger Through Sustainable Agricultural and Rural Development and Wider Access to Food", Paper Presented to the World Food Summit- Five Years Later, July. Rome FAO 44.

14. FAO, (2008). The State of Food Insecurity in the World 2008: High Food Prices and Food SecurityThreats and Opportunities. Available from ftp://ftp.fao.org/doc rep/faol 011/ i0291 e/i0291 00.pdf (accessed 7 May 2010).

15. Food Security and Nutrition Working Group (FSNWG), (2012). Response Plan Addressing the Food and Nutrition Crisis in the Sahel.2012 Strategic document Version 2-15 February.

16. Gokum, G. G. (2007), "Agricultural Development Programs and Food Security in Nigerian (19702004)" in Ogiji P. (ed.) The Nigerian Economy: Challenges \& Directions For Growth in the next 25 years.

17. Kankwenda, M., Gregoire, L, Legros, $H$ and Ouedraogo, $H$ (2010). Poverty Eradication Economical ltd London. 1-16.

18. Maziya-Dixton, B; Akinyele, I.O; Oguntona, E.B; Nokoe, S; Sanusi, R.A and Harris, E. (2004) Nigeria Food Consumption and Nutritional Survey 2001-2002. Summary International Institute for Tropical Agriculture.

19. Niger State Agricultural Development Project (NSADP), (2012). Niger State Agricultural Development Project Office, Maitunbi, Minna, Niger State.

20. Niger State Ministry of Agriculture, (2011). Niger State Ministry of Agriculture, Agricultural Department Office, Minna, Niger State.

21. Nworgu, F. C. (2006). Prospects and Pitfall of Agricultural Production in Nigeria. Ibadan, Blessed Publication Consultants/Publication.

22. Nyam, T.T. (2005). The Concept and Philosophy of the Special Programme for Food Security Paper presented at the Site level Sensitization workshop on Concepts and Philosophy of The Special Programme for Food Security held at Makurdi, Otukpo and Katsina-Ala Sites. March 16-20, 2005.

23. Odey, M.O. (2004). "Alternative Approaches to Food Security Strategies in Nigeria in the New Millennium" in Ogiji P. (ed) Implications for Food Security and Agricultural Reforms in Nigeria. Essays in Honor of David Iornongo Ker; The Food Basket Myth Aboki Publisher, Makurdi.

24. Oni, O., Pender, J., Philips, D. and Kato, E. (2009). Trends and Divers of Agricultural Productivity in
Nigeria. Nigeria Strategy Support Programme (NSSP) Report 001: IFPRI.

25. Sengooba, T. (1994). Root Crops for Food Security in Africa. In. Akorede M.O (ed.) Proceeding of the 5th Triennial Symposium of International Society of Tropical Root, Kampala, Uganda pp 23-25.

26. Todaro, .M. \& Smith, I. (2003). Economics for a Developing World. Longman Publishers: London.

27. United Nation Development Programme, (2010). What Will It Take to Achieve the Millennium

28. Vidal, S. (2007). "Global Food Crisis Looms as Climate Change and Fuel Shortages pile; Soaring Crop Prices and Demand for Bio-fuels Raise Fears of Political Instability" www.Guardian .co.uk Saturday November 3, 2007.

29. Vision, (2010). Agriculture, 1997: Final Report of the Sub-Committee on Agriculture Economic Sector, Abuja.

30. Wibberley, E. J (2005). Oil and Agriculture: Frameworks and Farmers for Food Security. Paper Presented at animal lecture organized by the centre for food agricultural Strategy, University of Agriculture, Makurdi, March 22, 2005.

31. World Bank \& IFPRI, (2006). Agriculture and achieving the Millennium Development Goals. Agriculture and Rural Development Department Report Number 32729-GLB.

32. World Bank, (1986).Poverty and Hunger: Issues and Options for Food Security in Developing Countries. A World Bank Policy Study, Washington D.C U.S.A pp 1-6.

33. World Bank, (2004). Global poverty down by half since 1981, but progress uneven as economic growth eludes many countries. News Release no. 2004/309/S, April 23, 2004. (http://www.worldbank.org/data/wdi2004/index.ht m) Accessed June 2009.

34. World Health Organization, (2004).Millennium Development Goals Report, Abuja. FGN/WHO

35. Yusuf, B. I, Baba; K.M., Mohammed, I. \& Dogondaji, S.D. (2009). "Determinants of rice Production: A guide for food security policy in Nigeria." In "sustaining Agricultural Growth to meet national economic development goal. "Proceedings of the 23rdAnnual Conference of the Farm Management Association of Nigeria, FAMAN 